\title{
Thank God it's just CovID!
}

\section{Alexander Donald Milliken}

Royal Jubilee Hospital, Victoria BC, Canada

Department of Psychiatry, University of British Columbia, Canada

\section{Abstract}

We have been lucky with the COVID-19 pandemic: it got the attention of the first world, yet (unlike other pandemics) has not threatened the very existence of humankind. COVID-19 has given us a chance to see how well we were prepared for something that was predictable.

Keywords: COVID-19 $\cdot$ Canada $\cdot$ pandemic $\cdot$ response $\cdot$ preparedness

\section{Citation}

Milliken AD. Thank God it's just COVID!. Eur J TransI Clin Med. 2020;3(2):7-10.

DOI: $10.31373 /$ ejtcm/128170

Graduating in medicine 55 years ago, I have lived through many epidemics. As a practicing psychiatrist watching what people say (or do not say) and using that information to make meaning, I know we have been lucky with the COVID pandemic [1-5]. It got the attention of the first world, yet (unlike others) has not threatened the very existence of humankind. It has given us a chance to see how well we were prepared for something that was predictable.

Epidemics occur regularly. In just the past 20 years, we have had SARS, MERS, swine flu, Ebola, H7N9 influenza, Zika, while dengue, malaria, measles, AIDS and TB continue and increase $[2,4,6]$. COVID morphed into a pandemic which affected us as well [4]. Some recent epidemics had a mortality rate of up to $40 \%$; if they had spread like COVID, we would be facing the modern equivalent of the Black Death [7]. From most, Canadians have been protected by our geography, or poor viral human to human transmission, but with 6 such threats in the past 18 years, will luck protect us again from the next one due in 2025 or 2030 [8]?

Frankly, our response has shown many flaws that would be disastrous with a more malignant infection. To start, we avoided acknowledging it and being clear about the danger. If the Chinese government waffled, and it did, Canadian federal politicians also dithered to avoid bad news [9]. Other countries (and my province of $\mathrm{BC}$ ) were calling for border closures and quarantining of travelers long before the feds acted. The Federal Minister of Health accused those asking about data reliability from China of pushing conspiracy theories, and later stopped Chief Public He-

Corresponding author:

Alexander Donald Milliken, Royal Jubilee Hospital, Victoria BC, Canada

e-mail: Dmilliken@live.ca

No external funds.

Available online: www.ejtcm.gumed.edu.pl

Copyright ${ }^{\circledR}$ Medical University of Gdańsk

This is Open Access article distributed under the terms of the Creative Commons Attribution-ShareAlike 4.0 International.

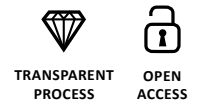


alth Officer Dr. Tam from answering questions about whether Ottawa had been warned that the national emergency stockpile, including PPE, had been underfunded - after we already knew that supplies were not rotated properly nor replaced [10]. Front line workers knew that supplies were scarce; the refusal to answer how long those supplies would last, and knowing they were unavailable in many care homes gave rise to legitimate fears which were not assuaged by political leaders of all stripes appearing like groundhogs sticking their heads out of their burrows, saying "We're here for you" and then disappearing again. This false reassurance was of little comfort for workers not only at an increased risk, but contributed to a continuing worry about workplace safety, which in some care homes led to the abandonment of their charges [11].

There was a gross lack of systemically collected important data. Some confusion is unavoidable with a new disease. But we know that the numbers of cases reported are unlikely to be the numbers infected, just those tested and found positive. Daily publication of deaths from around the world, while of great shock value, is even more suspect; we don't know how many extra deaths occurred without the infection being identified [12]. Deaths are clustered amongst those who are older, sicker, poorer and living in closer quarters, just as they are for any infection. In Canada, care homes for the elderly provide $80 \%$ of the fatalities; of the other $20 \%$, greater numbers are amongst health care and personal service workers $[11,13]$. We don't know why: working as they do, do they get increased viral exposure, and does this mean more serious illness? Is the lack of proper PPE a factor? Is it because of gender, or that many are from ethnic minorities? Is ethnicity a proxy for social disadvantage, or are there biological differences beyond melanin production [14]? Previous refusals to identify ethnicity in Canadian hospital data for purposes of virtue-signaling means we can only now start to ask [15].

Will there be a single second wave this fall or, like influenza, recurring waves? The long term trajectory of the illness - and our society - today is not in our hands: recurrences will depend on an as yet undiscovered successful vaccine, on how long immunity lasts and the level of immunity persisting in the herd [16]. With fewer compromised elderly left, previous epidemics have become less class or age conscious the second time around. Bending the curve has protected Canadian healthcare resources so we don't have the mass graves of Italy, New York or Brazil, scenes which would be familiar to a $14^{\text {th }}$ century caller of "Bring out your dead". Yet our $14^{\text {th }}$ Century response of closing the city gates, isolating the pest houses and avoiding those who might be affected (we call it lockdown and social distancing) has left us with deaths in solitary isolation, without family comfort or dignity [17].

If a second wave comes, as seems to be happening in Europe, the public health measures started three months ago will again flatten the curve, protecting health care services, but again at a great cost to society [18]. This playbook was written long ago, even before SARS. So, in 5 or 10 years' time, when COVID-19 hopefully becomes a memory, will we deal with the next plague better? We don't know what will cause it or exactly when, just that it will occur. If 10 years ago we knew what to do and had a negligent, ramshackle response, will we avoid it the next time?

As a 76 year old overweight physician, I do not want to die. Nevertheless, I prefer that COVID-19 affect me than my 46 year old child or my 16 year old grandchild. I have led my life, but if I die, I do not want to die alone, isolated, hungry, thirsty and in unchanged diapers. The deficiencies of the care home system have been well known for years; if the public report by the Canadian Armed Forces on the level of care came like a gut check, then the people in power were burying their heads in the sand [19]. For over 15 years, I have heard stories about colleagues visiting relatives in care homes daily to ensure care and that meals were eaten. Notwithstanding the calls from unions and politicians of the left, the care in the publically administered or non-profit institutions was only less inadequate than that in private ones. People of all political persuasions are advocating different solutions which reflect more their political world views than the reality of the data [20].

Here we come to the crux of this whole response problem: the first role of government must be to ensure that clinically appropriate standards, whether in public health, care homes or hospitals, are set in a transparent manner, and secondly to monitor and enforce those standards. This all governments, including many outside Canada, failed to do, including such simple standards as consistency of caregivers, time for care and adequacy of supplies [2, 21]. The dereliction of this important role by politicians of all stripes will not be solved by nationalization alone.

Not just business, but routine healthcare in Canada was been shut down due to a total lack of surge capacity. Every epidemic, including the annual flu outbreaks, produces a surge demand on the system [2]. For COVID, no-one can quarrel with the emptying of the beds to prepare for an unknown threat. What is obvious is that the system has been ground down so that this is the only way to deal with any surge, even seasonal flu. In 1970, Canada had 7 hospital beds per 1,000 population. By 1990, this had been reduced to 6 , but by 2012 , this number had been cut to an asto- 
unding 2.7 [20]. This reduction occurred in spite of the fact that many patients today have more complex illnesses, or require more complex treatments which contribute to our greater lifespans. As a physician who practiced in 1970, I know that many conditions are dealt with more efficiently now: however, this enormous reduction in bed capacity has been not been driven by lower clinical demand but by the drive of politicians of all political parties to reduce taxes [22]. The court cases by the clinicians of the Cambie Clinic and the patients in the Chaouilli decision in Quebec arguing against the governmental health care monopoly were not about wanting to pay more, but to have reasonable access to care, and what to do if that access was not available [23]. While unions and politicians cast these cases as private versus public, at their core they are a discussion of what the standards should be, and how should they be upheld? Governments surreptitiously bury standards, dismiss clinicians' concerns and avoid collecting the data for the necessary public and transparent discussion about accountability.

Our response to COVID has been enormously expensive [24]. Small business owners have been pillaged, bankruptcies and financial distress have left proud people in tears. Routine healthcare was shut down and non-COVID deaths increased [25]. The future tax burdens to pay back the increased public debt are currently unknown. While an epide- mic was predictable, preparation was ignored by those in political power, who should have been setting standards and enforcing them. The so-called "public administration" of healthcare enshrined in Canadian law has degenerated into political administration, without transparent accountability or a public source of truth. Five years ago, it may have cost a little more to keep adequate supplies of PPE, or provide good care in care homes. Today, we pay the price for not having done so.

Every unnecessary death is a waste. Every first responder or health care worker in unnecessary mortal fear is a cost. The COVID epidemic is bad enough, with an estimated infection fatality rate much lower than SARS or MERS [1-2]. For those who lost a loved one in isolated circumstances, each is a tragedy. But if we use it to demand three things: transparent accountability in the system; the provision of the essential requirements for a public healthcare system, and the elimination of the political legerdemain, next time we may be thankful COVID-19 came before COVID-25.

\section{Acknowledgements}

The author most gratefully acknowledges the co-operation and assistance of Tomasz Szmuda MD, PhD in the preparation of this article.

\section{References}

1. Zhu Z, Meng K, Liu G, Meng G. A database resource and online analysis tools for coronaviruses on a historical and global scale. Database [Internet]. 2020 Oct 3;baaa070:1-8. Available from: https://doi.org/10.1093/database/baaa070

2. Smiatacz T. It didn't have to happen this way - what COVID-19 tells us about translational medicine. Eur J TransI Clin Med [Internet]. 2020 May 29;3(1):7-10. Available from: https://doi.org/10.31373/ejtcm/119455

3. Li Q, Guan X, Wu P, Wang X, Zhou L, Tong Y, et al. Early Transmission Dynamics in Wuhan, China, of Novel CoronavirusInfected Pneumonia. N Engl J Med [Internet]. 2020 Mar 26;382(13):1199-207. Available from: http://www.nejm.org/ doi/10.1056/NEJMoa2001316

4. Cucinotta D, Vanelli M. WHO Declares COVID-19 a Pandemic. Acta Biomed [Internet]. 2020 Mar 19;91(1):157-60. Available from: http://www.ncbi.nlm.nih.gov/pubmed/32191675

5. Szmuda T, Ali S, Özdemir C, Syed MT, Singh A, Hetzger TV, et al. Edit Datasets and future research suggestions concerning the novel Coronavirus (COVID-19). Eur J Transl Clin Med. 2020;3(2):[ahead of pub].

6. Peeri NC, Shrestha N, Rahman MS, Zaki R, Tan Z, Bibi S, et al. The SARS, MERS and novel coronavirus (COVID-19) epidemics, the newest and biggest global health threats: what lessons have we learned? Int J Epidemiol [Internet]. 2020 Jun 1;49(3):717-26. Available from: http://www.ncbi.nlm.nih.gov/pubmed/32086938

7. Shaw-Taylor L. An introduction to the history of infectious diseases, epidemics and the early phases of the long-run decline in mortality†. Econ Hist Rev [Internet]. 2020 Aug 15;73(3):E1-19. Available from: https://onlinelibrary.wiley.com/ doi/abs/10.1111/ehr.13019

8. St-Denis X. Sociodemographic Determinants of Occupational Risks of Exposure to COVID-19 in Canada. Can Rev Sociol [Internet]. 2020 Aug 13;57(3):399-452. Available from: https://onlinelibrary.wiley.com/doi/abs/10.1111/cars.12288 
9. Rose J. The Mortal Coil of Covid-19, Fake News, and Negative Epistemic Postdigital Inculcation. Postdigital Sci Educ [Internet]. 2020 Oct 1;1-18. Available from: https://doi.org/10.1007/s42438-020-00192-7

10. Chase S. Health Minister says Canada has no evidence that China is under-reporting virus impact - The Globe and Mail [Internet]. 2020 [cited 2020 Oct 4]. Available from: https://www.theglobeandmail.com/canada/article-health-ministersays-canada-has-no-evidence-that-china-is-under/

11. Alam H. COVID-19 Infections Among Canadian Health-Care Workers Are Above Global Average | HuffPost Canada [Internet]. 2020 [cited 2020 Oct 4]. Available from: https://www.huffingtonpost.ca/entry/canadian-health-care-workerscovid-19-rates ca 5f67dcdcc5b6b9795b12ab4f?guce referrer=aHROcHM6Ly93d3cuZ29vZ2xILnBsLw\&guce referrer sig=AQAAANLHAEZ5-O 969gEjSIGh7kigavpFxf-hERe UxS-wYYSIRqKF7Jo8RetxRzpW2U5Cv\&guccounter=2

12. Blasius B. Power-law distribution in the number of confirmed COVID-19 cases. Chaos An Interdiscip J Nonlinear Sci [Internet]. 2020 Sep;30(9):093123. Available from: http://aip.scitation.org/doi/10.1063/5.0013031

13. Canada ranks worst in elderly care home coronavirus deaths: study [Internet]. 2020 [cited 2020 Oct 4]. Available from: https://medicalxpress.com/news/2020-06-canada-worst-elderly-home-coronavirus.html

14. Ahmed SB, Dumanski SM. Sex, gender and COVID-19: a call to action. Can J Public Heal [Internet]. 2020 Sep 29;1. Available from: http://link.springer.com/10.17269/s41997-020-00417-z

15. Mykhalovskiy E, Kazatchkine C, Foreman-Mackey A, McClelland A, Peck R, Hastings C, et al. Human rights, public health and COVID-19 in Canada. Can J Public Heal [Internet]. 2020 Sep 24;1. Available from: http://link.springer.com/10.17269/ $\underline{\text { s41997-020-00408-0 }}$

16. Kleen T-O, Galdon AA, MacDonald AS, Dalgleish AG. Mitigating Coronavirus Induced Dysfunctional Immunity for At-Risk Populations in COVID-19: Trained Immunity, BCG and "New Old Friends". Front Immunol [Internet]. 2020 Sep 4;11. Available from: https://www.frontiersin.org/article/10.3389/fimmu.2020.02059/full

17. Pietrabissa G, Simpson SG. Psychological Consequences of Social Isolation During COVID-19 Outbreak. Front Psychol [Internet]. 2020 Sep 9;11. Available from: https://www.frontiersin.org/article/10.3389/fpsyg.2020.02201/full

18. Cacciapaglia G, Cot C, Sannino F. Second wave COVID-19 pandemics in Europe: a temporal playbook. Sci Rep [Internet]. 2020 Dec 23;10(1):15514. Available from: http://www.nature.com/articles/s41598-020-72611-5

19. COVID-19: Read the Canadian Forces report on long-term care. TVOntatio [Internet]. 2020 [cited 2020 Oct 4]. Available from: https://www.tvo.org/article/covid-19-read-the-canadian-forces-report-on-long-article-care

20. Makarenko J. Canada's Health Care System: An Overview of Public and Private Participation | Mapleleafweb.com [Internet]. 2010 [cited 2020 Oct 4]. Available from: https://www.mapleleafweb.com/features/canada-s-health-care-system-overview-public-and-private-participation.html

21. Nakat Z, Bou-Mitri C. COVID-19 and the food industry: Readiness assessment. Food Control [Internet]. 2021 Mar;121:107661. Available from: https://linkinghub.elsevier.com/retrieve/pii/S0956713520305776

22. Palacios M, Barua B. The Price of Public Health Care Insurance 2018 /Fraser Research Bulletin [Internet]. 2018. Available from: https://www.fraserinstitute.org/sites/default/files/price-of-public-health-care-insurance-2018.pdf

23. Black C. The future of our health care is being decided in the courts [Internet]. 2018 [cited 2020 Oct 4]. Available from: http://www.conradmblack.com/1436/the-future-of-our-health-care-is-being-decided-in

24. How much does it cost to respond to the COVID- 19 crisis? - 4 May 2020 / Food Security Cluster [Internet]. 2020 [cited 2020 Oct 4]. Available from: https://fscluster.org/coronavirus/document/how-much-does-it-cost-respond-covid-19

25. Conti S, Ferrara P, Mazzaglia G, D'Orso MI, Ciampichini R, Fornari C, et al. Magnitude and time-course of excess mortality during COVID-19 outbreak: population-based empirical evidence from highly impacted provinces in northern Italy. ERJ Open Res [Internet]. 2020 Jul 27;6(3):00458-2020. Available from: http://openres.ersjournals.com/lookup/ doi/10.1183/23120541.00458-2020 